\title{
Chemical composition of Brachiaria ruziziensis and Chloris gayana as affected by age
} at harvest

$*^{1}$ Okukenu, O. A., ${ }^{1}$ Eesuola, A. A., ${ }^{1}$ Dele, P. A., ${ }^{1}$ Akinyemi, B. T. ${ }^{1}$ Amisu, A. A., 'Onifade,

O. S., 'Jolaosho, A. O., 'Owuye, O. A. and ${ }^{1}$ Adegboyega, S. S.

${ }^{I}$ Department of Pasture and Range Management,

Federal University of Agriculture, P. M. B. 2240, Abeokuta, Nigeria.

Abstract "Corresponding author:femiokukenu@yahoo.co.uk, 08033960216

Animal feeding is one of the major factors affecting the success of livestock rearing. However, the rhythm of harvest or grazing depends on the plant maturity which is one of the most important factors of grass-feeding-value variation. The research was conducted to evaluate the chemical composition of two tropical grasses (Brachiaria ruziziensis and Chloris gayana) as affected by the age of harvest. The study was laid out in a $2 \times 3$ factorial arrangement in a split plot design comprising of two grasses (Brachiaria ruziziensis and Chloris gayana) constituted the main plot while the age at harvest (3, 6 and 9 weeks) was the sub plots replicated thrice. Dry matter, crude protein, ether extract, ash, non fibre carbohydrate, neutral detergent fibre, acid detergent fibre, acid detergent lignin, hemicellulose, cellulose, macro and micro mineral contents were determined. Result showed that proximate composition of B. ruziziensis and C. gayana were not significant $(p>0.05)$ except crude protein $(C P)$ and ash contents. There was decline in CP contents as the grasses advanced in maturity in which grasses harvested at three weeks had highest CP (10.38\%) content. Also, the structural constituent's decreased as the grasses advanced in age. Irrespective of the grasses, the grass harvested at three weeks had the least NDF $(57.33 \%)$, $A D F(35.83 \%)$ and $A D L(7.00 \%)$ contents while the highest contents of NDF (61.33\%), ADF $(39.50 \%)$ and $A D L(10.00 \%)$ was recorded at nine weeks of harvesting. C. gayana harvested at three weeks had highest (10.95\%) CP content with the least (8.91\%) content recorded in B. ruziziensis harvested at 6 weeks. There were no significant $(p>0.05)$ different in ash content of B. ruziziensis harvested at 6 and 9 weeks while C. gayana harvested at 6 weeks had the least (7.33\%) content. Chloris gayana had higher contents of Ca $(3.96 \mathrm{~g} / \mathrm{kg}), P(3.28 \mathrm{~g} / \mathrm{kg})$, $\mathrm{Na}(1.73 \mathrm{~g} / \mathrm{kg}), \mathrm{Cu}(8.18 \mathrm{mg} / \mathrm{kg}), \mathrm{Zn}(47.27 \mathrm{mg} / \mathrm{kg})$ and Mn $(113.89 \mathrm{mg} / \mathrm{kg})$ than B. ruzizensis for both macro and micro mineral. There were no consistent trends in the mineral contents of both grasses at different age at harvest. It is therefore concluded that there were variations in the chemical composition of the two tropical grasses at different age at harvest.

Keywords: Fibre composition; grass; mineral contents; nutritional quality; proximate composition

\section{Composition chimique de Brachiaria ruziziensis et Chloris gayana selon l'âge à la} récolte

\section{Résumé}

L'alimentation animale est l'un des facteurs majeurs affectant le succès de l'élevage. Cependant, le rythme de récolte ou de pâturage dépend de la maturité de la plante qui est l'un des facteurs les plus importants de variation de la valeur graminée. La recherche a été menée pour évaluer la composition chimique de deux graminées tropicales (Brachiaria ruziziensis et Chloris gayana) en fonction de l'âge de la récolte. L'étude a été présentée dans un arrangement factoriel $2 \times 3$ dans une conception de parcelle divisée comprenant deux graminées (Brachiaria ruziziensis et Chloris gayana) constituaient la parcelle principale 


\section{Chemical composition of Brachiaria ruziziensis and Chloris gayana}

tandis que l'âge à la récolte (3, 6 et 9 semaines) était les sous-parcelles répliquées trois fois. Les teneurs en matière sèche, protéines brutes, extrait éthéré, cendres, glucides non fibreux, fibres détergentes neutres, fibres détergentes acides, lignine détergente acide, hémicellulose, cellulose, macro et micro minéraux ont été déterminées. Les résultats ont montré que la composition immédiate de B. ruziziensis et C. gayana n'était pas significative $(p>0,05)$, à l'exception des teneurs en protéines brutes $(P B)$ et en cendres. Il y a eu une baisse de la teneur en $P B$ à mesure que les graminées avançaient en maturité, les graminées récoltées à trois semaines ayant la teneur en PB la plus élevée (10,38\%). De plus, le constituant structurel diminue à mesure que les graminées vieillissent. Indépendamment des graminées, l'herbe récoltée à trois semaines avait les teneurs les plus faibles en NDF (57,33\%), ADF $(35,83 \%)$ et $A D L(7,00 \%)$ tandis que les teneurs les plus élevées en NDF (61,33\%), ADF (39,50\%) et ADL $(10,00 \%)$ a été enregistré à neuf semaines de récolte. C. gayana récolté à trois semaines avait la teneur en CP la plus élevée (10,95\%) avec la teneur la plus faible $(8,91 \%)$ enregistrée chez B. ruziziensis récolté à 6 semaines. Il n'y avait pas de différence significative $(p>0,05)$ dans la teneur en cendres de B. ruziziensis récolté à 6 et 9 semaines tandis que $C$. gayana récolté à 6 semaines avait la teneur la plus faible (7,33\%). Chloris gayana avait des teneurs plus élevées en Ca (3,96 g/ $\mathrm{kg}), P(3,28 \mathrm{~g} / \mathrm{kg}), \mathrm{Na}(1,73 \mathrm{~g} / \mathrm{kg}), \mathrm{Cu}(8,18 \mathrm{mg} / \mathrm{kg}), \mathrm{Zn}$ $(47,27 \mathrm{mg} / \mathrm{kg})$ et $\mathrm{Mn}(113,89 \mathrm{mg} / \mathrm{kg})$ que B. ruzizensis pour les macro et micro minéraux. Il n'y avait pas de tendances cohérentes dans la teneur en minéraux des deux graminées à différents âges à la récolte. Il est donc conclu qu'il y avait des variations dans la composition chimique des deux graminées tropicales à différents âges à la récolte.

Mots-clés : Composition des fibres ; herbe; teneur en minéraux ; qualité nutritionnelle; composition proche

\section{Introduction}

Ruminant production is one of the major livestock industries in most of the developing countries in the tropics (Okoruwa and Agbonlahor, 2016). Ruminant livestock play an important role in the economic development of Nigeria in terms of feeding the steadily growing population and providing the investible resources for national development. Inadequate nutrition is one of the major factors that generally affect livestock productivity. Despite the naturally endowed vegetations, there are still inadequate feeds and feedstuff for livestock in Nigeria. Period of dry season is always stressful for livestock, as the environment is characterized by insufficient feeds, occasioned by scarce forage and fibrous standing hays and the negative effect of the period is obvious in the loss of weight, reduced milk production and high mortality of the animals. Incidence of disease outbreak is rampant as a result of low immunity arising from malnutrition. Grass is the major source of nutrients for domesticated ruminants duringlarge part of the year (Taweel et al., 2005). Herrera (2004) argued that pasture turn out to be anappropriate source of food for ruminants, mainly in countries of tropical climate.

This is due tothe high number of species that can be used, possibility of cultivating them throughout the year, capacity of ruminant using fibrous foods, does not compete as food for humans and tends to be a cheap economical source. Grasses are more easily accessible, better in taste and quicker in digestion than shrubs and trees (Quraishi, 1999). Nutritive quality of forage has been defined as the product of the voluntary intake, digestibility and efficiency of nutrients that are used by the animal (Reid, 1994). The digestibility of the different grass species could be distinctly different, and is also influenced by area of 
origin, including temperature, light intensity, total rainfall, soil type, fertilization level, and by stage of maturity and preservation method (Jančík et al., 2009). Grasses are the most dominant plants in most forage based enterprises throughout the world. They provide energy and nutrients for animal growth and maintenance. Their leaves are more palatable than stems and re-growths are more nutritious than old tissues (Briske, 1991). Cattle and sheep feed on grass which form their major diet and are able to convert the vegetative matter into products such as milk and meat. There are many genera of grasses and numerous species ranging from short leafy grasses to tall coarse fibrous grasses. During the early stages of growth at the onset of the rains, the plants put out soft leaves which are very rich in protein and sugar. At this stage the contents within the cellulose cell wall are readily available to the animal. As the grass plant matures, the leaves reach their full size and contain less digestible protein and the carbohydrates which in turn are less available to the animal. Livestock production is successful based on the feedstuff given to them such as; grains, concentrates, forage on grazing or cut and carry. Forages are important in the feeding of ruminant's animals as it improves their productivity and it is a major form of nutrition. Animal feeding is one of the major factors of success in livestock raising. However, the rhythm of harvest or grazing depending on the plant maturity is one of the most important factors of grasses feeding value variation (Boyer and Roberge, 1985). The nutritive values of grasses had been studied by Patra et al. (2011) and Haribabu and Savithramma (2013) but studies on elemental analysis are scanty. Hence the present study tends to look at the effect of age at harvest on proximate composition, fibre composition and mineral contents of two tropical grasses.

\section{Materials and methods}

\section{Experimental site}

The experiment was carried out at the Cattle Production Venture (CPV) unit of the Federal University of Agriculture, Abeokuta (FUNAAB), Ogun State, Nigeria, located in the derived savannah zone of the southwest Nigeria on latitude $7^{\circ}$ $10^{\prime} \mathrm{N}$, longitude $3^{\circ} 2^{\prime} \mathrm{E}$ and altitude of $76 \mathrm{~m}$ above sea level while the laboratory experiment took place at the Department Of Pasture and Range Management laboratory Federal University of Agriculture, Abeokuta.

\section{Land preparation}

The land was ploughed and allowed to rest for two weeks before it was harrowed. The experimental land measuring $798 \mathrm{~m}^{2}$ was mapped out after harrowing. Prior to planting, soil samples were randomly collected from the field at depth of $0-15 \mathrm{~cm}$ using soil auger to represent the topsoil. The samples were bulked per replicate, mixed thoroughly and sub-samples were analyzed to determine the pre-planting nutrient status of the soil.

Sourcing and establishment of plant material

The seeds planted were Brachiaria ruziziensis and Chloris gayana. The seeds were obtained from National Animal Production Research Institute (NAPRI) Zaria and the seeds were broadcasted at the rate $10 \mathrm{~kg} / \mathrm{ha}$.

\section{Experimental design}

The study was laid out in a $2 \times 3$ factorial experiment in a split plot design. Two grasses (B.ruziziensis and C.gayana) constituted the main plot while the three (3) ages at harvest (3, 6 and 9 weeks) were in three replicates. The inter plot and intra-plot spaces were kept weed free throughout the experimental period by hand weeding.

\section{Laboratory analysis}

Proximate composition (dry matter, crude protein, ether extract and ash) was determined according to A.O.A.C. (2000) 


\section{Chemical composition of Brachiaria ruziziensis and Chloris gayana}

while non-fibre carbohydrate was calculated as $\mathrm{NFC}=100-(\mathrm{CP}+\mathrm{Ash}+\mathrm{EE}+$ NDF).Fibre fraction(Neutral detergent fibre (NDF), Acid detergent fibre (ADF) and Acid detergent lignin (ADL)) were determined with the procedure of Van Soest et al, (1991). Cellulose content was taken as the difference between ADF and ADL while hemicellulose content was calculated as the difference between NDF and ADF. Macro mineral $(\mathrm{Ca}, \mathrm{P}, \mathrm{K}, \mathrm{Mg}$ and $\mathrm{Na}$ ) and micro mineral contents ( $\mathrm{Fe}, \mathrm{Cu}, \mathrm{Zn}$ and $\mathrm{Mn}$ ) was determined. The content of Potassium (K) was estimated with a flame photometer after wet digestion in nitric acid and Hydrochloric acid (3:1). Contents of calcium, phosphorus, zinc, copper and iron were determined with atomic absorption spectrophotometry (Fritz and Schenk, 1979).

\section{Statistical analysis}

Data collected was subjected to two-way analysis of variance and the treatment means were separated using Duncan's Multiple Range Test using SAS (1999) package.

\section{Results}

There were no significant $(p>0.05)$ differences on the proximate and fibre composition of B. ruziziensis and Chloris gayana except for Crude protein (CP) and Ash contents (Table 1). The C. gayana had higher $(10.08 \%) \mathrm{CP}$ content and least $(8.78 \%)$ ash contents. Age at harvest had significant $(p<0.05)$ influenced on the proximate and fibre composition. The $\mathrm{CP}$ content declined as the grasses advanced in age as grasses harvested at 3 weeks had highest $(10.38 \%) \mathrm{CP}$ content while there was no significant $(p>0.05)$ difference between grasses harvested at 6 and 9 weeks. Structural constituents (NDF, ADF and ADL) increased as the grasses advance in maturity which follows this order $3<6<9$ weeks and the grasses harvested at 9 weeks had highest NDF (61.33\%), ADF (39.50\%) and ADL (10.00) contents (Table 1). The $C$. gayana harvested at 3 weeks had highest (10.95\%) CP content with the least (8.91\%) content recorded in $B$. ruziziensis harvested at 6 weeks. There were no significant $(\mathrm{p}>0.05)$ difference in ash content of $B$. ruziziensis harvested at 6 and 9 weeks while C. gayana harvested at 6 weeks had the least $(7.33 \%)$ content. NDF contents ranged from $56.00 \%$ in $B$. ruziziensis harvested at 3 weeks to $61.33 \%$ in both $B$. ruziziensis and $C$. gayana harvested at 9 weeks. C. gayana harvested at 9 weeks had highest (39.67\%) ADF content while $B$. ruziziensis harvested at 9 weeks had highest (10.67\%) ADL content (Table 2). There was significant $(p<0.05)$ variations in both macro and micro mineral contents of B. ruziziensis and $C$. gayana. Meanwhile, $C$. gayana had higher Ca $(3.96 \mathrm{~g} / \mathrm{kg}), \mathrm{P}(3.28 \mathrm{~g} / \mathrm{kg}), \mathrm{Na}(1.73$ $\mathrm{g} / \mathrm{kg}), \mathrm{Cu}(8.18 \mathrm{mg} / \mathrm{kg}), \mathrm{Zn}(47.27 \mathrm{mg} / \mathrm{kg})$ and $\mathrm{Mn}(113.89 \mathrm{mg} / \mathrm{kg})$ contents while $B$. ruziziensis had higher $\mathrm{K}(16.50 \mathrm{~g} / \mathrm{kg}), \mathrm{Mg}$ $(5.03 \mathrm{~g} / \mathrm{kg})$ and $\mathrm{Fe}(134.30 \mathrm{mg} / \mathrm{kg})$ contents (Table 3). There were also significant $(p<0.05)$ differences in both macro and micro mineral contents at different ages of harvest although it does not follow specific trends. Grasses harvested at 3 weeks had highest $\mathrm{Ca}(4.24 \mathrm{~g} / \mathrm{kg}), \mathrm{Na}(1.70 \mathrm{~g} / \mathrm{kg}), \mathrm{Fe}$ $(162.43 \mathrm{mg} / \mathrm{kg}$ ) contents compared to other age at harvest and there was no specific trend in macro and micro mineral contents of both B. ruziziensis and C. gayana harvested at different age at harvest (Table 4). 
Okukenu, Eesuola, Dele, Akinyemi, Amisu, Onifade, Jolaosho, Owuye and Adegboyega

Table 1: Proximate and fibre composition (\%) of Brachia riaruziziensis and Chloris gayana as affected age at harvest

\begin{tabular}{|c|c|c|c|c|c|c|c|c|c|c|}
\hline Factors & $\mathrm{DM}$ & $\mathrm{CP}$ & $\mathrm{EE}$ & Ash & NFC & $\mathrm{NDF}$ & $\mathrm{ADF}$ & $\mathrm{ADL}$ & HEM & CELL \\
\hline \multicolumn{11}{|l|}{ Grass } \\
\hline B. ruziziensis & 95.56 & $9.24^{\mathrm{b}}$ & 6.56 & $10.78^{\mathrm{a}}$ & 14.54 & 58.89 & 37.44 & 8.89 & 21.44 & 28.56 \\
\hline C. gayana & 96.67 & $10.08^{\mathrm{a}}$ & 5.89 & $8.78^{b}$ & 15.36 & 59.89 & 37.44 & 8.22 & 22.44 & 29.22 \\
\hline SEM & 0.43 & 0.20 & 0.42 & 0.43 & 1.20 & 1.14 & 0.64 & 1.11 & 0.69 & 0.59 \\
\hline \multicolumn{11}{|l|}{ Age at harvest } \\
\hline 3 (Weeks) & 96.67 & $10.38^{\mathrm{a}}$ & 5.50 & 9.67 & $17.12^{\mathrm{a}}$ & $57.33^{b}$ & $35.83^{\mathrm{b}}$ & $7.00^{\mathrm{b}}$ & 21.50 & 28.83 \\
\hline 6 & 95.17 & $9.29^{\mathrm{b}}$ & 6.33 & 9.50 & $15.38^{\mathrm{ab}}$ & $59.50^{\mathrm{a}}$ & $37.00^{\mathrm{b}}$ & $8.67^{\mathrm{ab}}$ & 22,50 & 28.83 \\
\hline 9 & 96.50 & $9.31^{\mathrm{b}}$ & 6.83 & 10.17 & $12.35^{\mathrm{b}}$ & $61.33^{\mathrm{a}}$ & $39.50^{\mathrm{a}}$ & $10.00^{\mathrm{a}}$ & 21.83 & 29.50 \\
\hline SEM & 0.51 & 0.21 & 0.49 & 0.60 & 1.24 & 0.56 & 0.45 & 0.46 & 0.87 & 0.52 \\
\hline
\end{tabular}

Table 2: Interaction effect of species and age at harvest on proximate and fibre composition (\%) of grasses

\begin{tabular}{|c|c|c|c|c|c|c|c|c|c|c|c|}
\hline Grass & $\begin{array}{l}\text { Age at } \\
\text { harvest }\end{array}$ & DM & $\mathrm{CP}$ & $\mathrm{EE}$ & Ash & $\mathrm{NFC}$ & $\mathrm{NDF}$ & $\mathrm{ADF}$ & $\mathrm{ADL}$ & HEM & CELL \\
\hline \multirow[t]{3}{*}{ B. ruziziensis } & 3 & 96.33 & $9.82^{\mathrm{b}}$ & 5.33 & $9.67^{\mathrm{ab}}$ & $19.18^{\mathrm{a}}$ & $56.00^{\mathrm{b}}$ & $36.33^{\mathrm{bc}}$ & $7.33^{\mathrm{b}}$ & 19.67 & 29.00 \\
\hline & 6 & 94.33 & $8.91^{\mathrm{d}}$ & 7.00 & $11.67^{\mathrm{a}}$ & $13.09^{\mathrm{ab}}$ & $59.33^{\mathrm{ab}}$ & $36.67^{\mathrm{abc}}$ & $8.67^{\mathrm{ab}}$ & 22.67 & 28.00 \\
\hline & 9 & 96.00 & $9.00^{\text {cd }}$ & 7.33 & $11.00^{\mathrm{a}}$ & $11.33^{\mathrm{b}}$ & $61.33^{\mathrm{a}}$ & $39.33^{\mathrm{ab}}$ & $10.67^{\mathrm{a}}$ & 22.00 & 28.67 \\
\hline \multirow[t]{3}{*}{ C. gayana } & 3 & 97.00 & $10.95^{\mathrm{a}}$ & 5.67 & $9.67^{\mathrm{ab}}$ & $15.05^{\mathrm{ab}}$ & $58.67^{\mathrm{ab}}$ & $35.55^{\mathrm{c}}$ & $6.67^{\mathrm{b}}$ & 23.33 & 28.67 \\
\hline & 6 & 96.00 & $9.67^{\mathrm{bc}}$ & 5.67 & $7.33^{\mathrm{b}}$ & $17.66^{\mathrm{ab}}$ & $59.67^{\mathrm{a}}$ & $37.33^{\mathrm{abc}}$ & $8.67^{\mathrm{ab}}$ & 22.33 & 28.67 \\
\hline & 9 & 97.00 & $9.63^{\mathrm{bcd}}$ & 6.33 & $9.67^{\mathrm{ab}}$ & $13.37^{\mathrm{ab}}$ & $61.33^{\mathrm{a}}$ & $39.67^{\mathrm{a}}$ & $9.33^{\mathrm{ab}}$ & 21.67 & 30.33 \\
\hline SEM & & 0.32 & 0.17 & 0.88 & 0.38 & 0.83 & 0.51 & 0.44 & 0.39 & 0.50 & 0.41 \\
\hline
\end{tabular}

Table 3: Mineral contents of Brachiaria ruziziensis and Chloris gayanaas affected by age at harvest

\begin{tabular}{|c|c|c|c|c|c|c|c|c|c|}
\hline \multirow[t]{2}{*}{ Factors } & $\mathrm{Ca}$ & $\mathrm{P}$ & $\mathrm{K}$ & $\mathrm{Mg}$ & $\mathrm{Na}$ & \multirow[t]{2}{*}{$\mathrm{Fe}$} & $\mathrm{Cu}$ & $\mathrm{Zn}$ & $\mathrm{Mn}$ \\
\hline & & & $\mathrm{g} / \mathrm{kg}$ & & & & \multicolumn{3}{|l|}{$\mathrm{mg} / \mathrm{kg}$} \\
\hline \multicolumn{10}{|l|}{ Grass } \\
\hline B. ruziziensis & $3.78^{\mathrm{b}}$ & $2.00^{\mathrm{b}}$ & $16.50^{\mathrm{a}}$ & $5.03^{\mathrm{a}}$ & $1.44^{\mathrm{b}}$ & $134.30^{\mathrm{a}}$ & $4.08^{\mathrm{b}}$ & $20.95^{\mathrm{b}}$ & $30.62^{b}$ \\
\hline C. gayana & $3.96^{\mathrm{a}}$ & $3.28^{\mathrm{a}}$ & $12.73^{b}$ & $4.90^{\mathrm{b}}$ & $1.73^{\mathrm{a}}$ & $112.58^{b}$ & $8.18^{\mathrm{a}}$ & $47.27^{\mathrm{a}}$ & $113.89^{\mathrm{a}}$ \\
\hline SEM & 0.19 & 0.36 & 1.22 & 0.22 & 0.09 & 13.52 & 1.45 & 5.45 & 5.75 \\
\hline \multicolumn{10}{|l|}{ Age at harvest } \\
\hline 3 (Weeks) & $4.23^{\mathrm{a}}$ & $2.26^{\mathrm{b}}$ & $16.30^{\mathrm{b}}$ & $4.54^{\mathrm{c}}$ & $1.70^{\mathrm{a}}$ & $162.43^{\mathrm{a}}$ & $1.82^{\mathrm{c}}$ & $15.91^{\mathrm{c}}$ & $53.52^{c}$ \\
\hline 6 & $3.81^{\mathrm{b}}$ & $3.81^{\mathrm{a}}$ & $10.44^{c}$ & $5.14^{\mathrm{b}}$ & $1.48^{\mathrm{c}}$ & $72.08^{c}$ & $9.43^{\mathrm{a}}$ & $47.35^{\mathrm{a}}$ & $90.93^{\mathrm{a}}$ \\
\hline 9 & $3.57^{\mathrm{c}}$ & $1.86^{\mathrm{c}}$ & $17.11^{\mathrm{a}}$ & $5.21^{\mathrm{a}}$ & $1.57^{\mathrm{b}}$ & $135.80^{\mathrm{b}}$ & $7.13^{\mathrm{b}}$ & $39.06^{\mathrm{b}}$ & $72.31^{\mathrm{b}}$ \\
\hline SEM & 0.22 & 0.36 & 1.64 & 0.24 & 0.12 & 10.16 & 1.06 & 5.89 & 18.62 \\
\hline
\end{tabular}

Table 4: Interaction effect of species and age at harvest on mineral contents of grasses

\begin{tabular}{|c|c|c|c|c|c|c|c|c|c|c|}
\hline \multirow[t]{2}{*}{ Grass } & \multirow{2}{*}{$\begin{array}{l}\text { Age at } \\
\text { harvest }\end{array}$} & \multirow[t]{2}{*}{$\mathrm{Ca}$} & \multirow[t]{2}{*}{$\mathrm{P}$} & \multirow{2}{*}{$\begin{array}{l}\mathrm{K} \\
\mathrm{g} / \mathrm{kg}\end{array}$} & \multirow[t]{2}{*}{$\mathrm{Mg}$} & \multirow[t]{2}{*}{$\mathrm{Na}$} & \multirow[t]{2}{*}{$\mathrm{Fe}$} & \multirow{2}{*}{$\begin{array}{l}\mathrm{Cu} \\
\mathrm{mg} / \mathrm{kg}\end{array}$} & \multirow[t]{2}{*}{$\mathrm{Zn}$} & \multirow[t]{2}{*}{$\mathrm{Mn}$} \\
\hline & & & & & & & & & & \\
\hline \multirow[t]{3}{*}{ B. ruziziensis } & 3 & $3.87^{\mathrm{d}}$ & $2.50^{\mathrm{b}}$ & $19.45^{\mathrm{b}}$ & $5.46^{\mathrm{b}}$ & $1.29^{c}$ & $144.63^{b}$ & $2.12^{\mathrm{d}}$ & $15.45^{\mathrm{e}}$ & $28.38^{f}$ \\
\hline & 6 & $3.29^{\mathrm{e}}$ & $2.11^{\mathrm{d}}$ & $7.74^{\mathrm{e}}$ & $5.01^{\mathrm{d}}$ & $1.65^{\mathrm{b}}$ & $114.04^{\mathrm{e}}$ & $8.79^{c}$ & $33.55^{\mathrm{c}}$ & $29.59^{\mathrm{e}}$ \\
\hline & 9 & $4.18^{c}$ & $1.39^{\mathrm{f}}$ & $22.32^{\mathrm{a}}$ & $4.63^{\mathrm{e}}$ & $1.37^{\mathrm{c}}$ & $144.21^{\mathrm{c}}$ & $1.32^{\mathrm{f}}$ & $13.84^{\mathrm{f}}$ & $33.89^{d}$ \\
\hline \multirow[t]{3}{*}{ C. gayana } & 3 & $4.59^{\mathrm{a}}$ & $2.02^{\mathrm{e}}$ & $13.15^{\mathrm{c}}$ & $3.63^{f}$ & $2.11^{\mathrm{a}}$ & $180.23^{\mathrm{a}}$ & $1.53^{\mathrm{e}}$ & $16.38^{\mathrm{d}}$ & $78.67^{\mathrm{c}}$ \\
\hline & 6 & $4.33^{b}$ & $5.51^{\mathrm{a}}$ & $13.14^{\mathrm{c}}$ & $5.28^{\mathrm{c}}$ & $1.31^{\mathrm{c}}$ & $30.12^{f}$ & $10.07^{\mathrm{b}}$ & $61.16^{\mathrm{b}}$ & $152.27^{\mathrm{a}}$ \\
\hline & 9 & $2.97^{f}$ & $2.32^{\mathrm{c}}$ & $11.89^{\mathrm{d}}$ & $5.79^{a}$ & $1.77^{\mathrm{b}}$ & $127.38^{d}$ & $12.95^{\mathrm{a}}$ & $64.27^{\mathrm{a}}$ & $110.72^{b}$ \\
\hline SEM & & 0.14 & 0.32 & 1.18 & 0.17 & 0.07 & 11.25 & 1.13 & 5.16 & 11.35 \\
\hline
\end{tabular}

a,ba, b...f: means in the same column with different superscript are significantly different $(\mathrm{p}<0.05)$

SEM: Standard error of mean 


\section{Chemical composition of Brachiaria ruziziensis and Chloris gayana}

\section{Discussion}

It is quite evident that there were great variations in the chemical composition of the grasses harvested at different agesof harvest as revealed in the study and there are many factors affecting chemical composition of forages such as stage of growth maturity, species or variety (Promkot and Wanapat, 2004). The decline in the $\mathrm{CP}$ contents with the advancement of plant age in this study agrees with the reports of Bilal et al. (2001) and Olanite et al. (2006). This might be due to increase in the cell wall structure and a decrease in the leaf-stem ratio of the grasses with the advancement in the age of the grasses. The non fibre carbohydrate (NFC) recorded in this study fell within the range (127-259 $\mathrm{g} / \mathrm{kg}$ ) reported by Anele et al. (2009) and this indicates that the NFC of the grasses can be easily degraded or fermented as NFC is a crude estimate of the carbohydrate pool that differ in digestibility from NDF. It has also been reported that NFC has a positive relationship with ammonia nitrogen $\left(\mathrm{NH}_{3}-\right.$ $\mathrm{N}$ ) utilization in the rumen (Tylutki et al., 2008). The structural constituents increased as harvesting age was delayed while the increasing NDF content with increase in harvesting age agreed with the report of Asmare (2016) for grass species. NDF content of forage varies widely, depending on species, maturity, and growing environment (Mahyuddin 2007). The NDF recorded is within the range of 600-650 $\mathrm{g} / \mathrm{kg}$ suggested as the critical limit above which efficiency of utilization of tropical forages by ruminants would be impaired (Van Soest, 1982; Muia, 2000) and the consistent increase in the concentration of NDF with advancement in plant age is in line with the report of Arthington and Brown (2005). The results obtained also showed a linear increase in ADF content with corresponding changes in the maturity age, which might be due to changes in leaf to stem ratio of the plants and an increase in cell wall lignification with advanced stages of growth as reported (Adane, 2003; Yihalem, 2004). The moderate fibre levels of the grasses in this study will be of help in facilitating the colonization of ingesta by rumen microorganism which in turn might induce higher fermentation rates, hence improving digestibility, intake and animal performance. The increase in the hemicellulose and cellulose contents was as a result of advancement in age of the plants. This is in consonance with report of Johnson et al. (1973). This will however, eventually lead to lower digestibility and consumption by livestock (Twidwell and Wegenhoft, 1999). Minerals are required by both plants and animals in critical and balance amount, the excess and deficiency both reduce the efficiency of vegetation and dependant livestock production. According to Onwuka and Akinsoyinu (1988), the presence of mineral elements in animal feed is vital for the metabolic processes of the animals. Calcium is a mineral element required for the maintenance, growth, production, and milk or beef production of animal species and ruminant animals require $\mathrm{Ca}$ and other minerals to maintain the microbial population in the rumen. Calcium contents of the grasses revealed a highly significant difference which agrees with the report of Gomide et al. (1969) that observed the range of calcium contents from $2.4-8.4 \mathrm{~g} / \mathrm{kg}$ in tropical grasses. This result meets the dietary calcium requirement of between $1.6-6.0 \mathrm{~g} / \mathrm{kg}$ for beef animals (NRC, 1980) and the requirement of different ruminant animals in terms of $\mathrm{Ca}$ concentration ranged between 1.8 to $8.2 \mathrm{~g} / \mathrm{kg}$ as reported by McDowell (1992; 1997). The trend in the change in content of $\mathrm{P}$ with plant maturity is in line with the report of Minson (1990). The $\mathrm{P}$ contents of the grasses fell within the recommended $(1-4.8 \mathrm{~g} / \mathrm{kg})$ requirements for different classes of ruminant animals as stated by McDowell (1992; 1997). 


\section{Conclusion}

The study showed variation in the chemical composition of Chloris gayana and Brachiaria ruziziensis in which C. gayana had higher crude protein (CP) content and $\mathrm{CP}$ content declined as the plant advance in age while the structural constituents increases. B. ruziziensis had the least content of mineral contents as compared to C. gayana and at different age at harvest, there was no specific trend in the mineral contents.

\section{Acknowledgements}

We profoundly appreciate Mr Idehen, John, the laboratory technologist of the Department of Pasture and Range Management for his assistant in the laboratory analysis of this research.

\section{References}

A.O.A.C. 2000. Official methods of analysis $15^{\text {th }}$ edition. Association of Official Analytical Chemists, Washington D.C.

Adane, K. 2003. Effects of stage of harvesting and fertilizer application on dry matter yield and quality of natural grass land in the high lands of north Showa MSc Thesis. The School of Graduate Studies, Alemaya University, Alemaya, Ethiopia. 96p.

Anele, U. Y., Arigbede, O. M., Südekum, K.-H., Oni, A. O., Jolaosho, A. O., Olanite, J. A., Adeosun, A. I., Dele, P. A., Ike, K. A. and Akinola, O. B. 2009. Seasonal chemical composition, in vitro fermentation and in sacco dry matter degradation of four indigenous multipurpose tree species in Nigeria. Animal Feed Science and Technology 154: 47-57.

Arthington, J. D. and Brown, W. F. 2005. Estimation of feeding value of four tropical forage species at two stages of maturity. Journal of Animal Science 83:1726-1731

Asmare B. 2016. Evaluation of the agronomic, utilization, nutritive and feeding value of deshograss (Pennisetumpedicellatum). Ph.D. Dissertation. Jimma University, $\mathrm{J} \mathrm{i} \mathrm{m} \mathrm{m} \mathrm{a,} \mathrm{E} \mathrm{t} \mathrm{h} \mathrm{i} \mathrm{o} \mathrm{p} \mathrm{i} \mathrm{a.}$ http://hdl.handle.net/10568/77741

Bilal, M. Q., Sarwar, M. and Ahmad, S. 2001. Effect of Stage of Growth and Nitrogen Fertilization on Protein Contents of Mott Grass and its Morphological Fractions. International Journal of Agriculture and Biology 3(1):39-41

Boyer, J. and Roberge, G. 1985. Étude Éco Physiologique De La Productivité De Quelques Graminées À Haut Rendement Fourrager Cultivées $\mathrm{Au}$ Sénégal I. Influence Des Conditions Matérielles D'exploitation Sur Les Valeurs En Matière Sèche $\mathrm{De} L \mathrm{~L}$ Production Sur Pied Et De De L'utilisation De L'eau. Revue $d^{\prime}$ E 1 e v a g e E t D e MédecineVétérinaire Des Pays Tropicaux, 38(4):339-352.

Briske, D. D. 1991.Developmental morphology and physiology of grasses. In: Heit-schmidt, R.K. and Stuth, J. W. ( eds) Grazing Management: An Ecologicftl Perspective. Timber Press, Portland, Oregon. pp. 85-108.

Fritz, J. S. and Schenk, G. H. 1979. Quantitative Analytical Chemistry. $4^{\text {th }}$ Ed., Allyn and Bacon, Inc., Boston, Massachusetts.

Gomide, J. A., Noller, C. H., Mott, G. O., Conrad, J. H. and Hill, D. L. 1969. Mineral composition of six tropical grasses as influenced by plant age and nitrogen fertilization. 
Agronomy Journal 61:120-123

Haribabu, R. and Savithramma, N. 2013. An Assessment of Nutrient Content Of Underutilized Grass Species Of South India. International Journal of Pharmacology and Biological Sciences. 4(3):334-340.

Herrera, R. S. 2004. Photosynthesis: tropical grasses, contribution to Physiology, grown for energy and fibre use in Finland. In Biomass for energy and industry, $10^{\text {th }}$ European Germany, 204-206

Jančík, F., Koukolová, V., Kubelková, P. and Čermák, B. 2009. Effects of grass species on ruminal degradability of silages and prediction of dry matter effective degradability. Czech Journalof AnimalScience 54, 315-323.

Johnson, W. L., Guerrero, J. and Pezo, D. 1973. Cell-wall constituents and in vitro digestibility of Napier grass. Journal of Animal Science 37:1255-1261

Mahyuddin, P. 2007. Chemical composition of leaf and stem of tropical grasses at different stage of $\begin{array}{lllllll}\mathrm{g} & \mathrm{r} & \mathrm{o} & \mathrm{w} & \mathrm{t} & \mathrm{h} & \end{array}$ JurnalProduksiTernakTerapan 9(3):153-159.

McDowell, L. R. 1992. Minerals in animal and human nutrition. Academic Press, San Diego, 524pp

McDowell, L. R. 1997. Minerals for grazing ruminants in tropical regions, 3rd edn. University of Florida, Gainesville, Florida, USA, $81 \mathrm{pp}$

Minson, D. J. 1990.Forage in Ruminant Nutrition. Academic Press, London, 483 pp.

Muia, J. M. K. 2000. Use of Napier grass to improve smallholder milk production in Kenya PhD Thesis. Wageningen Agricultural University. The Netherlands.
National Research Council (NRC) 1980. Mineral Tolerance of Domestic Animals. Washington, DC: National Academy Press

Okoruwa, M. I. and Agbonlahor, I. 2016. Replacement value of cocoa pod husk with soursop pulp meals for napier grass in the practical diet of west African dwarf sheep. European Journal of Agriculture and Forestry Research. 4(5) 1-11.

Olanite, J. A., Arigbede, O. M., Jolaosho, A. O., Onifade, O. S. and Alabi, B. O. 2006. Effect of cutting intervals on the dry matter yield and nutritive quality of two varieties of Panicum maximum in the humid zone of Nigeria. ASSET Series A6 (1): 171-180.

Onwuka, C. F. I. and Akinsoyinu, A. O. 1988. Mineral constituents of some browse plants used in ruminant feeding in southern Nigeria. Nigerian Journal of Animal Production 15: 57-62.

Patra, J. K., Mishra, R. R., Rout, S. D. and Tatoi, H. N. 2011. Assessment of Nutrient Content of Different Grass Species of Similipal Tiger Reserve, Orissa. World Journal of Agricultural Science 7: 3741.

Promkot, C. and Wanapat, M. 2004.Ruminal degradation and intestinal digestion of crude protein of tropical resources using nylon bag and three-step in vitro procedure in dairy Cattle. Proceedings of the Agricultural Seminar, Animal Science/Animal Husbandry. Held at Sofitel Raja Orchid Hotel 27-28 January.

Quraishi, M. A. 1999.Range Management in Pakistann, p. 14. University of Agriculture, Faisalabad, Pakistan.

Reid, R. L. 1994. Milestones in forage research. In: Forage Quality, 
Evaluation and Utilization (Ed. G. C. Fahey Jr). Based on the National Conference on Forage Quality, Evaluation and Utilization. University of Nebraska, Lincoln. 13-15 April 1994. pp. 1-58.

Statistical Analysis System Institute Inc. 1999. SAS/ 24. STAT Programme, Carry, NC: SAS Institute Inc.

Taweel, H. Z., Tas, B. M., Smit, H. J., Elgersma, A., Dijkstra, J. and Tamminga, S. 2005. Effects of feeding perennial ryegrass with an elevated concentration of watersoluble carbohydrates on intake, rumen function and performance of dairy cows. Animal Feed Science and Technology, 121(3-4), 243256.

Twidwell, E. D. and Wegenhoft, K. 1999. Forage quality and its value. A v a i a b 1 e o n 1 i n e : http://www.agecon.lsu.edu/Extens ion_Pubs/Forage/\%20Quality $\% 20$ and $\% 20$ Its $\% 20$ Value.pdf
Tylutki, T. P., Fox, D. G., Durbal, V. M., Tedeschi, L. O., Russell, J. B., Van Amburgh, M. E., Overton, T. R., Chase, L. E. and Pell, A. N. 2008. Cornell Net Carbohydrate and Protein System: A model for precision feeding of dairy cattle. Animal Feed Science and Technology 143: 174-202.

Van Soest, P. J. 1982. Nutritional Ecology of the Ruminant: Ruminant Metabolism, Nutritional Strategies, the Cellulolytic Fermentation and the Chemistry of Forages and Plant Fibres, O. \& B. Books, Corvallis, Oregon 375 pp

Van Soest, P. J., Robertson, J. B. and Lewis, B. A. 1991. Methods for dietary fibre, neutral detergent and non-starch polysaccharides in relation to animal nutrition. Journal of Dairy Science 74 (10):35833597.

Yihalem, D. 2004. Assessment of Botanical Composition and Stage of Harvesting of selected Natural Pasture for Optimum Utilization as Hay at Andassa Livestock Research Center, Northwestern Ethiopia. MSc. Thesis the School of Graduate Studies, Alemaya University. 99p.

Received: $27^{\text {th }}$ August, 2021 Accepted: $10^{\text {th }}$ December, 2021 